\title{
ANALYSIS OF ACTIVITY OF ENTERPRISES' SUBJECTS ON THE FOOD PRODUCTS MARKET
}

\section{АНАЛІЗУВАННЯ ДІЯЛЬНОСТІ СУБ'ЄКТІВ ПІДПРИСМНИЦТВА НА РИНКУ ХАРЧОВИХ ПРОДУКТІВ}

\author{
Stoyanovsky Andriy ${ }^{1}$ \\ Matsuk Vasylyna
}

DOI: https://doi.org/10.30525/978-9934-571-78-7_14

\begin{abstract}
The subject of the study is the analysis and evaluation of subjects of entrepreneurship in the food market. The purpose of the study is to conduct a thorough analysis of information provision in assessing the activities of business entities in the market of food products, as well as well as identify and typologies the factors that affect the effectiveness of business entities. Methodology. There is a certain unity in the interpretation of the concept of «economic efficiency» by modern scholars. It consists in the fact that this concept is characterized by a correlation between performance and cost of resources (time is also considered as a resource). Therefore, it is advisable that the assessment of the economic efficiency of the development of business structures in the food industry relies on a clear identification of objectives. Goals are a decisive factor in the selection of performance criteria. Thus, if the strategy of the development of business structures involves reducing the share of debt in the general structure of assets, then, on the basis of goal setting, the criterion of the effectiveness of the strategy for the development of business structures will be a certain value of the share of debt in the general structure of assets. According to the results of the conducted research, the only criterion for the success of the development of business structures is proposed - the difference between the «inflow» and the «outflow» of the funds of the entrepreneurial structure. In order to simplify the use of this criterion, in practice it is proposed to reduce the values that it can accept to two: «1»-the aggregate real equity capital of
\end{abstract}

${ }^{1}$ Candidate of Economic Sciences, Associate Professor

National University «Lviv Polytechnic», Ukraine

${ }^{2}$ Postgraduate Student,

National University «Lviv Polytechnic», Ukraine 


\section{Chapter «Economic sciences»}

an enterprise grows; «-1»-decreases. Using the proposed simplification of the criteria analysis of the effectiveness of the development of the business structure is convenient prediction of its values. This allows us to explore the development of the enterprise in the future. Conclusions. Decision-making on the implementation of entrepreneurial activities is often implemented in conditions of insufficient amount of reliable information, which requires the availability of information support, which allows not only to accumulate and process data, but also to complement them with probable assumptions formed on the basis of retrospective and prospective analysis. The formation of information support for decision-making can take place on the basis of several methods. It is most rational to take into account the results of alternative approaches, since this forms the most reliable informational basis for making managerial decisions. For the reasons mentioned above, in the study of the activities of food industry enterprises, the use of mathematical statistics can be significant, therefore, in this study, describes the use of this approach in the implementation of empirical and prospective analysis. As shown below, such an analysis should include (G)ARCH models, deviation criteria from the average, forward-looking analysis based on regression and modification, and also the measurement of the factors of the internal environment from external factors. All these components make it possible to form the most complete picture of the state of the investigated phenomenon or process that may take place at the food industry. This analysis can be conducted to analyze not only economic phenomena or processes, but also purely production-technological.

\section{1. Вступ}

Враховуючи необхідність детального опису інформаційного забезпечення, оскільки воно відіграє вагому роль при прийнятті рішень щодо подальшої підприємницької діяльності розглянемо послідовність реалізації пропонованого економіко-математичного аналізу. Варто зауважити, що чим більшим $є$ масив даних тим більш точними $є$ прогностичні властивості регресійних моделей. Також це дає змогу більш абстраговано дослідити динаміку відхилення від середньої величини і тим самим відкинути аномально високі або низькі значення досліджуваних показників. Процес збору та аналізу даних умовах швидкозмінного зовнішнього та внутрішнього середовища підприємства відбувається безперервно. Це дає змогу оперативно оновлювати базу знань та 
доповнювати іiї більш точними математичними моделями, які характеризуються точнішими прогностичними властивостями. Це також дозволяє вчасно відкинути не вагомі чинники та враховувати актуальну інформацію. Враховуючи великі масиви даних, які доводиться збирати, використання сучасних технологій машинного збору та обробки даних $є$ незамінним. У сучасному світі, інформація будь-якого типу може виявитись вирішальною. Експерти володіють великим досвідом, проте вони не здатні швидко зібрати дані із багатьох джерел, систематизувати їх, класифікувати та зробити відповідні висновки. Тому експертне опитування є незамінним при стратегічному аналізі.

У свою чергу, при статистичному аналізі діяльності підприємств харчової промисловості, можливим є використовувати дві групи методів: методи, орієнтовані на дослідження рівня відхилення динамічного ряду від випадкової величини; методи, які базуються на регресії, що дозволяє провести емпіричний та перспективний аналіз, а також дослідити рівень залежності факторів внутрішнього середовища від факторів зовнішнього.

Наукова новизна виконаного дослідження полягає у поєднанні результатів застосування двох вищенаведених груп методів обробки даних для аналізу інформаційного забезпечення при оцінюванні діяльності суб'єктів підприємництва на ринку харчових продуктів, а також ідентифікування та типологізації факторів, які впливають на ефективність діяльності суб'єктів підприємництва.

\section{2. Аналізування інформаційного забезпечення при оцінюванні діяльності суб' єктів підприємництва на ринку харчових продуктів}

Перша група методів базується на врахуванні такого показника, як дисперсія, який характеризує рівень відхилення випадкової величини від середнього арифметичного за певний період часу. Це дає змогу виявити рівень нестабільності динаміки досліджуваного процесу або явища. Проте, такий аналіз також є важливим при виявленні аномальних періодів у динаміці досліджуваних показників, оскільки на його основі можливим є виявити екстремальні відхилення дисперсії від іiі середнього значення за певний період. У практиці наукових досліджень для ідентифікування суттєвого відхилення використовується група із трьох критеріїв: «2 сигма», «3 сигма» та «6 сигма». Вибір між дослід- 


\section{Chapter «Economic sciences»}

жуваними критеріями слід здійснювати з урахуванням ситуаційного підходу, оскільки кожне підприємство є унікальним і потребує індивідуальних рішень. Вибір між критеріями можна здійснити на основі такого правила: кількість сигма відповідає порядку величини ${ }^{1}$ індексу останнього спостереження за випадковою величиною. Так, якщо кількість спостережень за досліджуваними показниками становить 998, то слід обрати «2 сигма», якщо 9998, то варто обрати «3 сигма» і т.д. Це правило $\epsilon$ обгрунтоване тим, що чим більший діапазон спостережень за випадковою величиною, тим більше може бути ії відхилення, i тому значення сигма обране для сотень спостережень може виявитись не суттєвим для діапазону в тисячі спостережень. Тому вибір між критеріями слід здійснювати на основі кількості спостережень за випадковою величиною. Питання про доцільність вибору десяткового значення сигми слід відкинути, оскільки порядок величини може вимірюватись тільки натуральними числами.

За умови коли виявлено відхилення із вищенаведеним критерієм, можна прийняти такі висновки: 1) динаміка досліджуваного процесу або явища характеризується впливом інших не врахованих чинників. Для прикладу, при дослідженні динаміки попиту на певну продукцію, виявлення такого відхилення може свідчити про зміну структури попиту, та доцільність зміни маркетингової стратегії; 2) високий рівень відхилення за певний період часу говорить про те, що наявний можливий критерій для класифікації стану певного явища або процесу. Для прикладу, при дослідженні ринків, на основі відхилення «n-сигма», можливим $є$ виявити сезонний характер зміни попиту на певні товари або послуги; 3) періодичне досягнення певного значення «n-сигма» може свідчити про наявність «пам'яті» досліджуваного динамічного ряду. Це говорить про те, що при реалізації перспективного аналізу, доцільним є враховувати значення за попередні часові періоди.

Явище зміни дисперсії для певного досліджуваного динамічного ряду у часі часто має місце в економіці, оскільки предметом ії вивчення виступає поведінка рефлективних процесів, учасниками яких виступають ірраціонально мислячі суб'єкти, котрі при побудові прогнозу часто використовують значення минулих періодів, характеризуються певним рівнем емоційності та діяльність яких не завжди має раціо-

\footnotetext{
${ }^{1}$ Порядок величини - це наближене значення десяткового логарифму числа.
} 
нальне пояснення. Тому у практиці статистичного аналізу фінансових ринків часто використовують моделі ARCH або їх узагальнену версію GARCH, на основі яких можливим $є$ дослідити тенденцію зміни дисперсії та прогнозувати іiі.

Вперше цей тип моделей був запропонований американським економістом Р. Еглом у 1982 р., за що у 2003 р. був удостоєний Нобелівської премії. Ідея Енгла полягала у тому, що значення дисперсії можна прогнозувати, що дає змогу прийняти рішення про рівень нестабільності у майбутньому та наскільки досліджувана випадкова величина буде доступною для прогнозування [1]. На основі цього типу моделей можливим було встановити рівень ризику у майбутніх періодах при аналізування динаміки фінансових ринків. Під час аналізування діяльності суб' єктів харчової промисловості, використання цього типу моделей може мати вагоме значення, оскільки дає змогу відстежити перспективну зміну дисперсії у майбутньому.

Класичне математичне представлення ARCH моделі $є$ наступним:

$$
\delta_{t}^{2}=a_{0}+\sum_{i=1}^{q} a_{i} x_{t-i}^{2}
$$

де $\delta_{t}^{2}-$ дисперсія випадкової величини за період від нульового періоду до періоду з індексом $t$, част. од.; $a_{0}$ - нульовий коефіцієнт лінійної моделі, част. од.; $x_{t-i}^{2}-$ квадрати значень випадкової величини за і-ий період, ум. од.; $a_{i}$ - лінійний коефіцієнт, використовується для зважування значень випадкової величини за певний і-ий період, част од.; $q$ - кількість лагових ${ }^{2}$ періодів.

На основі рівняння (1) можна підсумувати, що моделі ARCH базуються на дослідженні взаємозв'язку між значеннями дисперсії за певний період часу та відповідними зваженими значеннями за минулі періоди. Висновки зроблені на основі застосування моделей $\mathrm{ARCH}$ можуть мати вагоме значення при прийнятті управлінських рішень, оскільки вони дозволяють попереджати «розворотні» точки на ринку, встановити потенційні місця у виробничих процесах, де може виникати брак, виявляти нові ніші на основі дослідження конкурентних ринків, а також при прогнозуванні цін на ресурси. Роль моделей типу ARCH та приклад їх використання буде наведено нижче.

2 Лаговий період - це часовий період на який значення незалежної змінної відстають від значень залежної змінної. 


\section{Chapter «Economic sciences»}

Модель типу ARCH знайшла широке застосування у економетриці. У 1986 р. данський економіст Т. Боллереслев запропонував узагальнене представлення моделі, яке враховує не тільки значення випадкової величини, а й значення дисперсії. Модель Боллереслева може бути представлена наступним чином:

$$
\delta_{t}^{2}=a_{0}+\sum_{i=1}^{q} a_{i} x_{t-i}^{2}+\sum_{i=1}^{q} \beta_{i} \delta_{t-i}^{2},
$$

де $\beta_{i}-$ лінійний коефіцієнт, який враховує вплив лагових значень дисперсії.

Сьогодні існують різні модифікації цієї моделі, проте всі вони особливі випадки їх застосування. Для цілей цього дослідження достатнім $\epsilon$ використовувати GARCH-модель Боллереслева. Наведені математичні інтерпретації зазначений моделей використовують лінійну залежність. Це зумовлено тим, що для отримання лінійних коефіцієнтів використовується метод найменших квадратів, а самі моделі є різновидом регресійних моделей. Проте це не заперечує можливість використання залежностей інших видів, до яких можна віднести показникову функцію, логарифмічну, степеневу, синусоїду, косинусоїду тощо. Всі ці функції можуть бути отримані, шляхом відповідної маніпуляції із значеннями випадкової величини. Тоді, узагальнене математичне формулювання моделей умовної гетероскедастичності може бути описане наступним виразом:

$$
\delta_{t}^{2}=f\left(x_{q}, \delta_{q}^{2}\right), q \in[i ; t) .
$$

Вибір відповідного типу залежності слід здійснювати за наступними критеріями: 1) функція має бути здатною відобразити залежності від прискореного/уповільненого зростання/спадання; 2) функція має бути визначеною на інтервалі від нуля до нескінченності; 3) функція має бути нелінійною, оскільки це дозволяє врахувати ірраціональні чинники, що впливають на процеси та явища у економіці; 4) функція має бути зручною для отримання із використанням методу найменших квадратів.

Враховуючи ці критерії, оберемо степеневу залежність у (G)ARCH моделях

$$
\delta_{t}^{2}=a_{0} \prod_{i=1}^{q} x_{t-i}^{2 a_{i}} \prod_{i=1}^{q} \delta_{t-i}^{2 \beta_{i}} .
$$

Рівняння (4) дає є моделлю GARCH Боллереслева для степеневої залежності. Вибір степеневої залежності дає змогу дослідити вплив 
ірраціональних чинників, таких як досвід, репутація компанії, емоційність суб'єктів, які приймають управлінські рішення тощо. Всі ці фактори впливають на дисперсію нелінійно і тому використання лінійного зважування лагових значень не $є$ коректним. Наприклад, високий рівень відхилення на вартість ресурсів у минулому може вплинути на ціни у майбутньому, оскільки виробники включать високий ризик у ціну. Проте, згідно із класичним тлумаченням, це рівень ризику завжди однаково впливатиме на значення майбутньої ціни, в той час, як степенева залежність відображатиме цю залежність більш точно враховуючи можливі комбінації нелінійної зміни коефіцієнта, який відображає вплив вартості ресурсів на ціну товару. Так, високий ризик, з часом може стати звичним явищем (наприклад, це характерно для вітчизняного ринку пального), тому ціна змінюватиметься нелінійно-прискорено за умови незначного зростання ризику або уповільнено, оскільки при розрахунку майбутньої ціни також може враховуватися поведінка конкурентів та інші фактори.

Степеневі коефіцієнти для моделі (4) можна розрахувати на основі методу найменших квадратів, які дозволяє при певних маніпуляціях із вхідними даними отримати лінійні коефіцієнти, що можуть використовуватись як степеневі. Приведемо приклад таких маніпуляцій на основі моделі GARCH з одним лагом:

$$
\delta_{t}^{2}=a_{0} x_{t-1}^{2 a_{1}} \delta_{t-1}^{2 \beta} .
$$

Нехай дано модель (5), і необхідним є розрахувати степеневі коефіцієнти та нульовий коефіцієнт. 3 цією метою доцільним є перетворити вираз (5) так:

$$
\begin{aligned}
& \ln \left(\delta_{t}^{2}\right)=\ln \left(a_{0} x_{t-1}^{2 a_{1}} \delta_{t-1}^{2 \beta}\right) \Rightarrow \ln \left(\delta_{t}^{2}\right)=\ln \left(a_{0}\right)+\ln \left(x_{t-1}^{2 a_{1}}\right)+\ln \left(\delta_{t-1}^{2 \beta}\right) \Rightarrow \\
& \Rightarrow \ln \left(\delta_{t}^{2}\right)=\ln \left(a_{0}\right)+a_{1} \ln \left(x_{t-1}^{2}\right)+\beta \ln \left(\delta_{t-1}^{2}\right) .
\end{aligned}
$$

На основі перетворень (6) степеневу залежність (5) вдалось звести до лінійної форми, що свідчить про можливість використання методу найменших квадратів, проте після розрахунку натуральних логарифмів для вхідних рядів даних. Після, того як отримано рівняння (6), запишемо степеневу залежність:

$$
\delta_{t}^{2}=\exp \left(a_{0}\right) x_{t-1}^{2 a_{1}} \delta_{t-1}^{2 \beta}
$$

де ехр - функція експоненти ${ }^{3}$.

\footnotetext{
${ }^{3}$ функція піднесення константи е до певного степеня.
} 


\section{Chapter «Economic sciences»}

Модель GARCH степеневої форми залежності може бути отримана на основі методу найменших квадратів. Перед іiі побудовою необхідним є розрахунок значень логарифмів для вхідних рядів даних. Окрім моделей (G)ARCH для моделювання перспективного стану підприємства необхідним є використовувати регресійні моделі. Це можна здійснити на основі використання звичайних регресійних моделей, побудованих для групи чинників. Тоді форма рівняння, яке буде використовуватись може бути записана наступним чином:

$$
f(x, y, \ldots, z)=a_{0} x^{a_{1}} y^{a_{2}} \ldots z^{a_{n}},
$$

де $f(x, y, \ldots, z)$ - функція залежності певного результуючого параметра від досліджуваних показників, ум. од.; $a_{0}, a_{1}, a_{2}, \ldots, a_{n}$ - регресійні коефіцієнти, част. од.; $x, y, \ldots, z$ - значення незалежних змінних, ум. од.

У рівнянні (8) наведено степеневу залежність, переваги іiі використання, я також методи побудови уже було наведено вище. Це нелінійна форма залежності, а отже, на iï основі можливим $є$ дослідити вплив ірраціональних чинників, таких як досвід, репутація, емоційна складова у прийнятті рішень тощо. Всі ці фактори не можуть бути описані сталими лінійними коефіцієнтами у різні періоди діяльності підприємства. Більше того, оцінити їх кількісно у формі певної динаміки також неможливо, можливим $є$ виміряти їх вплив через непрямий підхід до врахування залежності (8). Так, якщо до рівняння (8) включити вплив фактора часу, представленого на основі ряду натуральних чисел із однаковою зміною протягом усіх часових періодів, то рівень перевищення степеневого коефіцієнту інших факторів над фактором часу буде описувати рівень пришвидшеного або уповільненого розвитку того чи іншого процесу. Повнішу інформацію може надати саме функція зміни степеневих коефіцієнтів. Якщо ця функція є зростаючою, то високим рівень врахування попереднього досвіду, покращення стану підприємства, посилення ним своїх ринкових позицій тощо, в залежності від того, які вхідні дані обрано для аналізу. Тому функція (8) набуде такої форми:

$$
f(x, y, \ldots, z)=a_{0} t^{k} x^{a_{1}} y^{a_{2}} \ldots z^{a_{n}}, t \in N,
$$

де $t$ - ряд натуральних чисел, який описує зміну часових індексів для періодів спостереження за випадковою величиною; $k$ - степеневий коефіцієнт для складової часу, част. од. 


\section{Stoyanovsky Andriy, Matsuk Vasylyna}

На основі степеневих коефіцієнтів рівняння (9), можливим є визначити стан досліджуваних процесів у порівнянні із результуючим параметром. Наприклад, дано функцію залежності чистого прибутку від обсягу інвестицій. Тоді, якщо складова часу має більший степеневий коефіцієнт ніж обсяги інвестицій, це говорить про їх не значущість у формуванні чистого прибутку підприємства. Це також доводить, що інвестиції впливають на значення прибутку з уповільненням або значним відставанням у часі. Приклад такого співвідношення дає підстави корегувати процес інвестування, можливо вибрати інші об'єкти для вкладання коштів, сформувати нову систему прийняття рішень, збільшити або зменшити обсяги інвестицій тощо. Порівняння степеневих коефіцієнтів незалежних змінних із 1 не дає остаточної відповіді на питання наскільки швидко досліджувані процеси або явища впливають на результуючий параметр, тому підхід із порівнянням степеневого коефіцієнта складової часу є більш раціональним.

При умові коли відбувається порівняння із багатьма параметрами, виникає необхідність розглянути декілька можливих варіантів: $\min \left(k, a_{1}, a_{2}, \ldots, a_{n}\right)=k$ - всі показники впливають на результуючий показник прискорено у часі, це свідчить про те, що підприємство враховує досвід, вміло застосовує здобуту репутацію тощо; $M\left(a_{1}, a_{2}, \ldots, a_{n}\right)>k$ - математичне сподівання степеневих коефіцієнтів для незалежних змінних $є$ більшим за коефіцієнт часу, це говорить, що в цілому досліджувані параметри сприятливо впливають на результуючий параметр; $\max \left(k, a_{1}, a_{2}, \ldots, a_{n}\right)=k-$ підприємство не враховує досвід минулих періодів або він $\epsilon$ несприятливим, його репутація погіршується, стан підприємства не варто описувати, як потенційно перспективний. У результаті, можливим є встановити рівень перспектив розвитку підприємства, міру урахування ним попереднього досвіду, а також те, чи покращується його репутація, чи нівелюється несприятливий вплив емоційної складової тощо. Недоліком представлених вище моделей $є$ те, що вони базуються на інформації у формі числових рядів. Тому варто розуміти, що модель може вважатись адекватною лише тоді, коли вона спирається на великий масив даних. Тому збір даних та їх повторне врахування у практиці моделювання діяльності підприємства не повинен припинятись. Чим більші масиви даних тим більш точними є відповідні моделі. Отже, інформаційне забезпечення суб'єктів підприємництва у сфері харчової промисловості скла- 


\section{Chapter «Economic sciences»}

датиметься із трьох головних складових - система збору даних, аналізу та прийняття рішень (рис. 1).

Перша складова включатиме автоматизовану і не автоматизовану систему збору даних для збору масивів даних про поведінку користувачів, зокрема, у соціальних мережах. Друга складова (система аналізу даних) включатиме статистичний аналіз та експертне опитування в залежності від того на який період здійснюється планування. Так, якщо необхідно сформувати прогноз щодо стратегічного періоду у 10 і більше років, то варто звернутися до досвіду експертів, оскільки на таких великих періодах математичний аналіз може виявитись не точним через недосконалість та викривлення ретроспективної інформації, яка завжди притаманна динамічним рядам даних. Проте, якщо необхідно швидко прийняти певне рішення про зміну виробничої структури чи оптимізацію структури інвестицій, то математичний аналіз $є$ прийнятним рішенням, оскільки він на основі взаємодії із системою збору даних дає змогу моделювати поведінку тих чи інших явищ, що стає підгрунтям для прийняття рішень. Система прийняття рішень не є одним із етапів менеджменту, на якому формуються управлінські рішення. Ця система включає в себе інструменти інтерпретації результатів експертного опи-

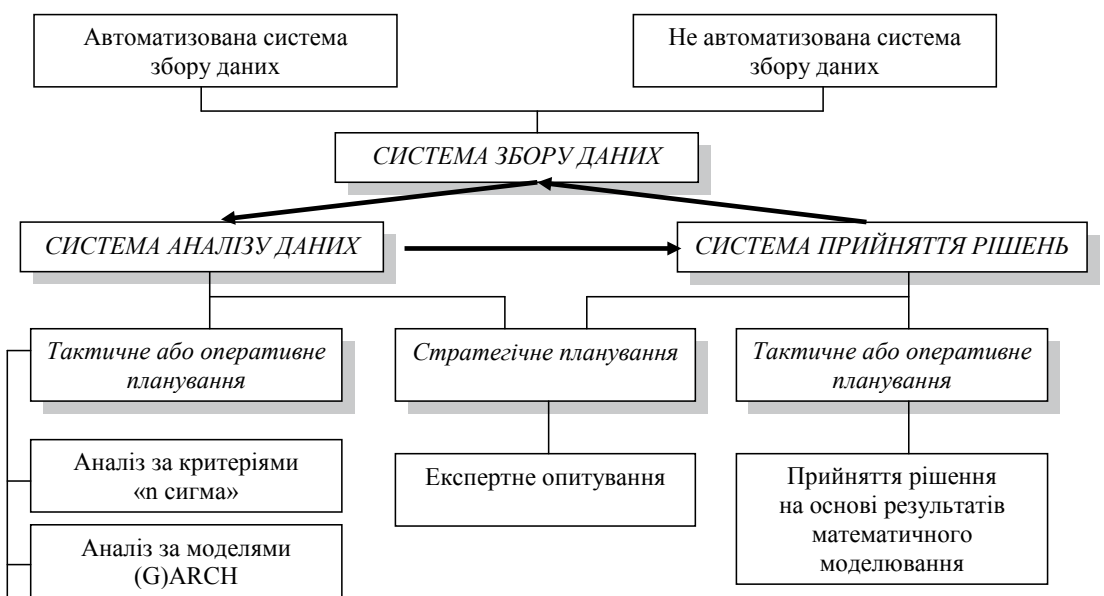

Регресійний аналіз

Рис. 1. Інформаційне забезпечення суб'сктів підприсмництва 
тування або економіко-математичного аналізу. Так, якщо це експертне опитування, то ця складова інформаційного забезпечення включає аналіз рівня узгодженості думок експертів, оскільки це дає підстави судити про істотність результатів їх опитування. Якщо йдеться про економіко-математичне моделювання, то система прийняття рішення включає перевірку статистичної значущості отриманих моделей, визначає рівень їх похибки тощо. На цьому етапі інформація необхідна для прийняття рішення доповнюється даними про якість дослідження.

\section{3. Ідентифікування та типологізація факторів, які впливають на ефективність діяльності суб'єктів підприємництва}

На основі попереднього дослідження було доведено, що при прийняття стратегічних рішень, варто надавати перевагу досвіду експертів. Математичний аналіз є більш дієвим на коротких часових проміжках, тому може використовуватись під час тактичного та оперативного планування. Аналіз факторів та визначення їх вагомості являється елементом дослідження із довгостроковим ефектом, тому для вирішення цього завдання було прийнято рішення використовувати експертне опитування. Базуючись на попередніх теоретичних пошуках, визначено, що до факторів які найбільш вагомо впливають на ефективність діяльності суб'єктів підприємництва на ринку харчових продуктів можна віднести такі: 1) наявність маркування за міжнародними стандартами якості; 2) відповідність продукції міжнародним стандартам якості; 3) глибина запровадження системи контролю якості, а саме НАССР; 4) рівень диверсифікації підприємства на споживчих ринках; 5) територіальне розташування виробничих потужностей підприємства; 6) рівень технічного устаткування; 7) досвід та інтелектуальний потенціал підприємства; 8) законодавча база; 9) рівень менеджменту на підприємстві; 10) система постачання ресурсами.

Експертам було запропоновано оцінити перелічені фактори за шкалою від 10-ти до 100-та у порядку зростання вагомості чинника. Всі чинники обрані так, щоб характер взаємозв'язку між ними був якомога менш суттєвим. Деякі чинники представляють внутрішнє середовище підприємства, інші зовнішнє. Метою є встановити які чинники є найбільш вагомо впливають на ефективність діяльності підприємств, які працюють на ринку харчових продуктів, на даному етапі розвитку ринкових відносин в Україні. При прийняті рішення щодо вибірки респондентів, які мають бути опитані, було встановлено прийнятну похибку на рівні 0,15 . 
Загальна сукупність експертів складала 356 осіб, з них 22-ві особи виділялись серед інших високим індексом цитованості ${ }^{4}$. Тоді кількість респондентів, яких необхідно було опитати можна розрахувати так:

$$
k=\frac{\frac{22}{356}\left(1-\frac{22}{356}\right)}{0,15^{2}} 2^{2} \approx 10 .
$$

Таким чином, із обраної сукупності експертів необхідно опитати щонайменше 10 осіб, для збереження похибки дослідження в межах до $15 \%$. В результаті опитування експертами було виставлено бальні оцінки вагомості досліджуваних факторів. Результати наведено у табл. 1.

Після того, як бальні оцінки виставлені, необхідним $є$ визначити їх вагомість. Це можна здійснити на основі такої формули:

$$
a_{i}=\frac{1}{N} \sum_{j=1}^{N} a_{i j}
$$

де $N$ - загальна кількість експертів; $a_{i j}-i$-ий фактор, оцінений $j$-им експертом.

Таблиця 1

Бальні оцінки виставлені експертами для оцінювання вище перелічених факторів

\begin{tabular}{|c|c|c|c|c|c|c|c|c|c|c|}
\hline \multirow{2}{*}{ Експерти } & \multicolumn{10}{|c|}{ Фактори, бали } \\
\cline { 2 - 11 } & $\mathbf{A}$ & $\mathbf{B}$ & $\mathbf{C}$ & $\mathbf{D}$ & $\mathbf{E}$ & $\mathbf{F}$ & $\mathbf{G}$ & $\mathbf{H}$ & $\mathbf{J}$ & $\mathbf{K}$ \\
\hline I & 60 & 20 & 70 & 80 & 60 & 20 & 70 & 40 & 50 & 30 \\
\hline II & 50 & 80 & 40 & 80 & 70 & 30 & 20 & 30 & 70 & 60 \\
\hline III & 60 & 20 & 30 & 70 & 90 & 40 & 80 & 50 & 40 & 60 \\
\hline IV & 30 & 30 & 70 & 20 & 30 & 20 & 40 & 20 & 70 & 20 \\
\hline V & 100 & 30 & 60 & 30 & 50 & 20 & 10 & 50 & 60 & 10 \\
\hline VI & 60 & 40 & 20 & 40 & 40 & 30 & 40 & 10 & 30 & 50 \\
\hline VII & 100 & 70 & 40 & 30 & 20 & 60 & 70 & 80 & 60 & 50 \\
\hline VIII & 20 & 80 & 60 & 30 & 80 & 70 & 40 & 20 & 20 & 50 \\
\hline IX & 100 & 50 & 20 & 30 & 50 & 60 & 40 & 80 & 20 & 20 \\
\hline X & 60 & 20 & 10 & 80 & 80 & 40 & 50 & 20 & 40 & 70 \\
\hline
\end{tabular}

Умовні позначення: літера фактора відповідає його порядковому номеру у вищенаведеному переліку досліджуваних чинників.

${ }^{4}$ Йдеться про індекс Херша в наукометричній базі Google Scholar, експерт вважався високо цитованим, якщо його індекс становив більше рівне 10-ти. 


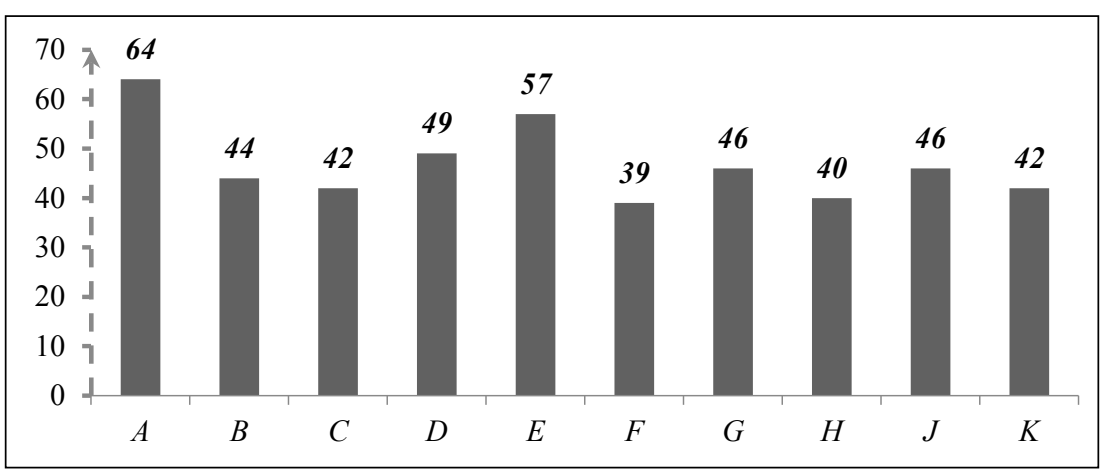

Рис. 2. Вагомість факторів, розрахована за формулою (2.10)

Якщо вагомість кожного із експертів є різною, то доцільним є введення додаткових коефіцієнтів вагомості, проте в даному випадку, обрано експерти із однаково високим індексом цитованості, тому доцільним є використовуватись формулу (10). На рис. 2 представлено значення вагомості за факторами.

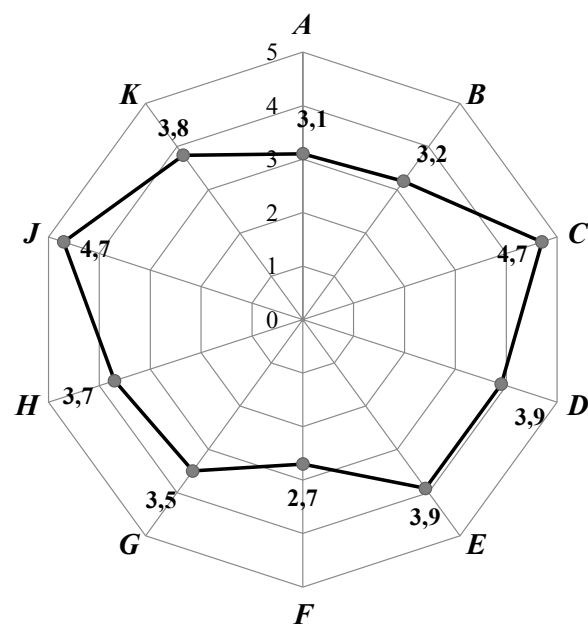

Рис. 3. Середні арифметичні рангові оцінки досліджуваних факторів
Як бачимо 3 рис. 2, фактори $A$ та $F$ характеризуються найвищим рівнем вагомості. Проте загалом всі фактори знаходяться приблизно на однаковому рівні щодо їх важливості. Окрім аналізу бальних оцінок при дослідження результатів експертного опитування також використовується ранжирування. Ранги - це ті ж оцінки тільки виставлені у порядку спадання за зростанням вагомості факторів в діапазоні від 1 до 10. У табл. 2 представлено результати ранжирування.

На рис. 3 представлено середнє арифметичне рангових оцінок факторів. 
Ранги факторів

\begin{tabular}{|c|c|c|c|c|c|c|c|c|c|c|}
\hline \multirow{2}{*}{ Експерти } & \multicolumn{10}{|c|}{ Фактори, бали } \\
\cline { 2 - 12 } & $\mathbf{A}$ & В & $\mathbf{C}$ & $\mathbf{D}$ & $\mathbf{E}$ & $\mathbf{F}$ & $\mathbf{G}$ & $\mathbf{H}$ & J & K \\
\hline I & 4 & 1 & 9 & 8 & 6 & 1 & 8 & 6 & 6 & 4 \\
\hline II & 3 & 9 & 5 & 9 & 7 & 3 & 2 & 5 & 9 & 8 \\
\hline III & 3 & 1 & 4 & 8 & 9 & 5 & 9 & 6 & 4 & 8 \\
\hline IV & 2 & 2 & 8 & 1 & 2 & 1 & 2 & 2 & 8 & 2 \\
\hline V & 5 & 2 & 6 & 1 & 3 & 1 & 1 & 5 & 6 & 1 \\
\hline VI & 2 & 2 & 2 & 4 & 2 & 1 & 1 & 1 & 3 & 3 \\
\hline VII & 4 & 4 & 3 & 1 & 1 & 3 & 5 & 4 & 5 & 3 \\
\hline VIII & 1 & 4 & 4 & 1 & 3 & 4 & 1 & 1 & 1 & 3 \\
\hline IX & 4 & 4 & 3 & 2 & 2 & 4 & 2 & 4 & 2 & 2 \\
\hline X & 3 & 3 & 3 & 4 & 4 & 4 & 4 & 3 & 3 & 4 \\
\hline
\end{tabular}

На основі рис. 3, можна підсумувати, що експерти вагаються щодо вибору особливо вагомих факторів. Усі досліджувані чинники характеризуються відносно однаковим рівнем вагомості. Це доводить, що більш точних результатів необхідно провести глибший аналіз результатів опитування експертів. Так, доцільним є розрахувати середню вагомість кожного із факторів по кожному із експертів. Це можна здійснити за формулою:

$$
\omega_{i}=\frac{\sum_{j=1}^{N} \omega_{i j}}{\sum_{i=1}^{M} \sum_{j=1}^{N} \omega_{i j}} \quad \omega_{i j}=\frac{\lambda_{i j}}{\sum_{i=1}^{M} \lambda_{i j}}
$$

де $\lambda_{i j}$ - оцінка в балах $i$-го фактору $j$-им експертом; $\omega_{i j}-$ частка оцінки в балах $i$-го фактору для $j$-го експерту; $M$ - кількість досліджуваних чинників; $N$ - кількість обраних для опитування експертів.

Результати розрахунків за формулою (11) наведено у табл. 3.

Найбільш вагомим виявились фактори $A$ та $E$, проте усі інші чинники також визнані вагомим. Для прогнозування впливу чинників на стан підприємства необхідним є застосування зваженого середнього, коефіцієнти якого можна отримати експертним методом. Ці коефіцієнти розрахуємо за формулою: 
Таблиця 3 Значення відносних оцінок факторів по кожному із опитаних експертів

\begin{tabular}{|c|c|c|c|c|c|c|c|c|c|c|}
\hline \multirow{2}{*}{$\begin{array}{c}\text { Екс- } \\
\text { перти }\end{array}$} & \multicolumn{10}{|c|}{ Фактори } \\
\cline { 2 - 12 } & $\mathbf{B}$ & $\mathbf{C}$ & $\mathbf{D}$ & $\mathbf{E}$ & $\mathbf{F}$ & $\mathbf{G}$ & $\mathbf{H}$ & $\mathbf{J}$ & $\mathbf{K}$ \\
\hline 1 & 0,154 & 0,138 & 0,138 & 0,123 & 0,108 & 0,092 & 0,092 & 0,062 & 0,046 & 0,046 \\
\hline 2 & 0,145 & 0,161 & 0,129 & 0,113 & 0,113 & 0,113 & 0,081 & 0,065 & 0,048 & 0,032 \\
\hline 3 & 0,125 & 0,139 & 0,125 & 0,111 & 0,111 & 0,097 & 0,083 & 0,083 & 0,069 & 0,056 \\
\hline 4 & 0,156 & 0,141 & 0,125 & 0,125 & 0,109 & 0,094 & 0,078 & 0,063 & 0,063 & 0,047 \\
\hline 5 & 0,137 & 0,137 & 0,123 & 0,110 & 0,110 & 0,096 & 0,082 & 0,082 & 0,068 & 0,055 \\
\hline 6 & 0,148 & 0,131 & 0,164 & 0,115 & 0,098 & 0,098 & 0,082 & 0,066 & 0,049 & 0,049 \\
\hline 7 & 0,136 & 0,136 & 0,152 & 0,121 & 0,106 & 0,091 & 0,076 & 0,076 & 0,061 & 0,045 \\
\hline 8 & 0,136 & 0,169 & 0,153 & 0,119 & 0,102 & 0,085 & 0,085 & 0,068 & 0,051 & 0,034 \\
\hline 9 & 0,161 & 0,129 & 0,145 & 0,113 & 0,113 & 0,081 & 0,097 & 0,065 & 0,048 & 0,048 \\
\hline 10 & 0,139 & 0,139 & 0,111 & 0,097 & 0,125 & 0,083 & 0,083 & 0,083 & 0,069 & 0,069 \\
\hline $\begin{array}{c}\text { У серед- } \\
\text { ньому }\end{array}$ & 0,1437 & 0,142 & 0,1365 & 0,1147 & 0,1095 & 0,093 & 0,0839 & 0,0713 & 0,0572 & 0,0481 \\
\hline
\end{tabular}

$$
w_{j}=\frac{\frac{1}{N} \sum_{i=1}^{N} r_{i j}}{\sum_{j=1}^{S}\left(\frac{1}{N} \sum_{i=1}^{N} r_{i j}\right)},
$$

де $w_{j}$ - коефіцієнт вагомості $j$-го фактора; $r_{i}$ - оцінка в балах $i$-го фактора для $j$-го експерта; $N$ - кількість опитаних експертів; $S$ - кількість досліджуваних чинників.

Результати розрахунків за формулою (12) наведено на рис. 4.

Отримані коефіцієнти вагомості можуть використовуватись у подальшому аналізі та наукових дослідженнях, зокрема, для обчислення інтегрованих показників тощо. Враховуючи те, що більшість факторів оцінені приблизно в однаковому діапазоні вагомості, необхідним є провести аналіз рівня узгодженості думок експертів. 3 цією метою розраховується низка коефіцієнтів. Одним із них є коефіцієнт конкордації, який можна обчислити за формулою:

$$
K_{\text {kon }}=\frac{\sum_{i=1}^{N} \beta_{i}^{2}}{\frac{1}{12}\left[M^{2}\left(N^{3}-N\right)-M \sum_{j=1}^{M} \alpha_{i}\right]} \text {, де } \beta_{i}=A r_{i}-\frac{\sum_{i=1}^{N} A r_{i}}{N}, a \alpha_{i}=\sum_{h=1}^{H}\left(l_{h}^{3}-l_{h}\right),
$$


де $H$ - загальна кількість груп, в яких рангові оцінки є однаковими; $l_{h}$ - загальна кількість однакових за значенням рангових оцінок в групі.

Значення коефіцієнта конкордації знаходяться в межах від нуля до одиниці. Чим ближчим до одиниці $\epsilon$ значення коефіцієнта тим вищою $\epsilon$ міра узгодженості думок опитаних експертів. В результаті розрахунків отримано, що

$$
K_{\text {kon }}=\frac{46594}{\frac{1}{12}\left[25^{2}\left(10^{3}-10\right)-25 \times 324\right]}=0,916
$$

Для перевірки статистичної значимості коефіцієнту конкордації, використовується критерій Пірсона, фактичне значення якого порівнюється

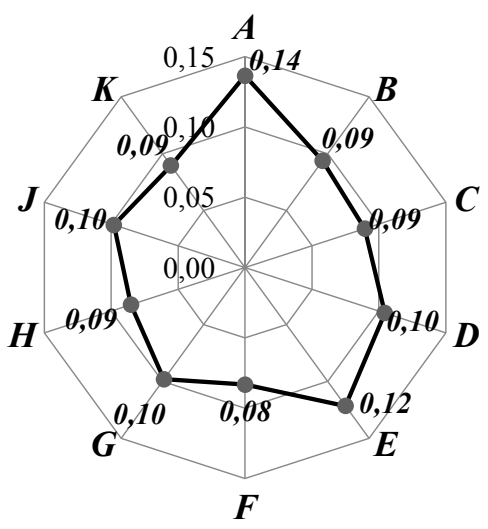

Рис. 4. Відносні оцінки вагомості факторів, оцінених за шкалою від 0 до 1, так щоб всі оцінки в сумі були рівними 1 iз відповідним табличним значенням, внаслідок чого приймається рішення про те, чи варто довіряти коефіцієнту конкордації. Фактичне значення критерію Пірсона можна обчислити за формулою:

$$
\chi_{f}^{2}=\frac{\sum_{i=1}^{N} \beta_{i}^{2}}{\frac{1}{12}\left[M N \times(N+1)-\frac{1}{N-1} \sum_{j=1}^{M} \alpha_{i}\right]}=\frac{46594}{\frac{1}{12}\left[25 \times 10 \times(10+1)-\frac{1}{10-1} \times 324\right]}=206,02 \text {. }
$$

Для довірчої ймовірності 0,99, табличне значення критерію Пірсона складає 21,66, що є меншим за його фактичне значення. Отже, коефіцієнт конкордації, що розрахований вище, є статистично значимим, а саме його значення доводить, що думки експертів $є$ узгодженими. Для більш повного аналізу узгодженості думок експертів можна повторити розрахунок коефіцієнту конкордації із виключенням одного із експертів. У табл. 4 наведено результати обчислень.

На основі табл. 4 можна відзначити, що жоден із експертів не має суттєвого впливу на рівень узгодженості думок між опитаними респондентами. Це ще раз доводить, що експерти оцінювали досліджувані фактори незалежно одне від одного, приймаючи рішення виключно 


\section{Значення коефіціснтів конкордації}

при виключенні одного із експертів

\begin{tabular}{|c|c|c|}
\hline $\begin{array}{c}\text { Експерт, який } \\
\text { виключасться }\end{array}$ & Коефіціснт конкордації & Критерій Пірсона $\left(\chi_{f}^{2}\right)$ \\
\hline 0 & 0,916 & 206,02 \\
\hline 1 & 0,913 & 197,22 \\
\hline 2 & 0,915 & 197,65 \\
\hline 3 & 0,914 & 197,44 \\
\hline 4 & 0,914 & 197,35 \\
\hline 5 & 0,914 & 197,33 \\
\hline 6 & 0,914 & 197,4 \\
\hline 7 & 0,914 & 197,36 \\
\hline 8 & 0,914 & 197,46 \\
\hline 9 & 0,914 & 197,52 \\
\hline 10 & 0,918 & 198,32 \\
\hline
\end{tabular}

на основі власного досвіду та знань. Це також підтверджує високий рівень узгодженості думок між ними.

Всі попередні дослідження рівня узгодженості думок експертів базуються на основі дослідження їх оцінок. Альтернативним способом дослідити рівень узгодженості думок експертів є розрахувати коефіцієнти кореляції між досліджуваними факторами. Це можна здійснити за формулою:

$$
R_{\tau, \phi}=1-\frac{\sum_{i=1}^{M}\left|E_{R, \tau, i}-E_{R, \phi, i}\right|^{2}}{\frac{1}{6}\left(M^{3}-M\right)-\frac{1}{12}\left(T_{\tau}+T_{\phi}\right)},
$$

де $T_{\tau}, T_{\phi}$ - значення зв'язаних рангових оцінок, виставлених опитаними експертами $\tau$, $\varphi$, які розраховуються аналогічно до коефіцієнта конкордації.

У табл. 5 представлено кореляційну матрицю, обчислену за формулою (15).

На основ кореляційної матриці, представленої у табл. 5, можна підсумувати, що бальні оцінки, виставлені факторам, характеризуються високою кореляцією. Це говорить, що експерти все ж таки погоджуються в оцінці їх вагомості. 
Таблиця 5

Кореляційна матриця при попарному порівнянні оцінок, виставлених факторам

\begin{tabular}{|c|c|c|c|c|c|c|c|c|c|c|}
\hline & $\mathrm{A}$ & $\mathrm{B}$ & $\mathrm{C}$ & $\mathrm{D}$ & $\mathrm{E}$ & $\mathrm{F}$ & $\mathrm{G}$ & $\mathrm{H}$ & $\mathrm{J}$ & $\mathrm{K}$ \\
\hline A & & 0,954 & 0,957 & 0,978 & 0,975 & 0,969 & 0,960 & 0,957 & 0,991 & 0,938 \\
\hline B & 0,954 & & 0,985 & 0,963 & 0,985 & 0,939 & 0,945 & 0,966 & 0,926 & 0,932 \\
\hline C & 0,957 & 0,985 & & 0,957 & 0,991 & 0,945 & 0,969 & 0,985 & 0,936 & 0,951 \\
\hline D & 0,978 & 0,963 & 0,957 & & 0,978 & 0,936 & 0,936 & 0,948 & 0,951 & 0,929 \\
\hline E & 0,975 & 0,985 & 0,991 & 0,978 & & 0,945 & 0,960 & 0,966 & 0,954 & 0,966 \\
\hline F & 0,969 & 0,939 & 0,945 & 0,936 & 0,945 & & 0,988 & 0,951 & 0,960 & 0,864 \\
\hline G & 0,960 & 0,945 & 0,969 & 0,936 & 0,960 & 0,988 & & 0,969 & 0,951 & 0,889 \\
\hline H & 0,957 & 0,966 & 0,985 & 0,948 & 0,966 & 0,951 & 0,969 & & 0,942 & 0,917 \\
\hline J & 0,991 & 0,926 & 0,936 & 0,951 & 0,954 & 0,960 & 0,951 & 0,942 & & 0,932 \\
\hline K & 0,938 & 0,932 & 0,951 & 0,929 & 0,966 & 0,864 & 0,889 & 0,917 & 0,932 & \\
\hline
\end{tabular}

\section{4. Висновки}

У результаті проведеного дослідження можна підсумувати, що експерти погоджуються у своїй точці зору щодо вагомості досліджуваних чинників. Найважливішими визначеного чинник А та Е. Ці фактори мають найвищий рівень важливості при дослідження поведінки суб' єктів підприємництва на ринку харчових продуктів. Варто зауважити, що інші враховані фактори є також важливими, коефіцієнти вагомості для них є значно вищими за $8 \%$. Тобто, можна підсумувати, що хоча, респонденти обрали декілька найбільш важливих чинників, все ж інші фактори, вони також розглядають, які такі що мають бути враховані при проведенні аналізування діяльності суб’ єктів підприємництва на ринку харчових продуктів. Важливим $\epsilon$ те, що чинникам зовнішнього середовища експерти надали лише 18\% вагомості. Це свідчить про те, що підприємства $є$ успішними передусім завдяки власним внутрішнім можливостям. Протягом років незалежності відбувається перехід від централізовано керованої форми державного регулювання економіки до ринкової. Принцип «laissez-faire» ${ }^{5}$ так і не був запроваджений у повній мірі, оскільки законодавча база часто переглядається, змінюються вимоги до звітності, змінюється фіскальна політика. Це може свідчити про низький рівень інвестиційної привабливості України. Проте, все ж

\footnotetext{
${ }^{5}$ Принцип не втручання уряду в економіку, дослівний переклад «лінь - справедлива».
} 
думка експертів говорить, що внутрішнє середовище підприємства $є$ більш вагомим для його успіху ніж зовнішнє. Це вказує на те, що досвід підприємства, його репутація, система менеджменту, використання міжнародного маркування, запровадження сучасних систем контролю якості продукції є вирішальними чинниками успішності підприємства, яке працює у сфері харчових продуктів. Варто зазначити, що експерти також наділили територіальне розміщення високим рівнем вагомості, це говорить про те, що підприємства такого типу прив'язані географічно до ринків постачання і збуту. Прикладом цього можуть служити кластер туризму в Кам'янці-Подільському, розвиток якого сприяє становлення дрібного підприємництва у сфері харчових технологій в регіоні. В результаті опитування експертів можна також підсумувати, що в цілому сучасна вітчизняна модель ведення бізнесу у досліджуваній галузі знаходиться на етапі формування.

\section{Список літератури:}

1. Engle et al. Estimating Time Varying Risk Premia in the Term Structure: The Arch-M Model // Econometrica. - 1987. - T. 55, № 2 (March). - P. 391-407.

2. Плюта Ю.С., Батрак І.О., Тарасенко І.О. Фінансове планування на підприємстві та напрями його вдосконалення. Формування ринкових відносин. 2014. № 7(158). С. 56-58.

3. Филимоненков А.С. Финансы предприятий. Киев: Ника-Центр, Эльга, 2002. $280 \mathrm{c}$.

4. Партин Г.О., Загородній А.Г. Фінанси підприємств. Національний банк України. Львівський банківський інститут. Львів: ЛБІ НБУ, 2003. 265 с.

\section{References:}

1. Engle et al. Estimating Time Varying Risk Premia in the Term Structure: The Arch-M Model // Econometrica. - 1987. - T. 55, № 2 (March). - P. 391-407.

2. Plyuta, Yu.S., Batrak, I.O. and Tarasenko, I.O. (2014). «Financial planning at the enterprise and directions of its improvement». Formation of market relations, vol. 7(158). pp. 56-58.

3. Filimonenkov, A.C. (2002). Finansy predprijatij [Finances of enterprises]. Nika-Center, Elga, Kyiv, Ukraine.

4. Partin, G.O. and Zagorodniy, A.G. (2003). Finansy pidpryiemstv [Business Finance]. LBI NBU, Lviv, Ukraine. 